\title{
"The impact of oil price crisis on financial performance of commercial banks in Bahrain"
}

\begin{tabular}{|c|c|}
\hline \multirow{5}{*}{ AUTHORS } & Iqbal Thonse Hawaldar (D https://orcid.org/0000-0001-7181-2493 \\
\hline & R https://publons.com/researcher/1456475/iqbal-thonse-hawaldar/ \\
\hline & \multirow{2}{*}{$\begin{array}{l}\text { Babitha Rohit } \\
\text { Prakash Pinto iD https://orcid.org/0000-0001-8168-9679 }\end{array}$} \\
\hline & \\
\hline & Rajesha T. M. \\
\hline ARTICLE INFO & $\begin{array}{l}\text { lqbal Thonse Hawaldar, Babitha Rohit, Prakash Pinto and Rajesha T. M. (2017). } \\
\text { The impact of oil price crisis on financial performance of commercial banks in } \\
\text { Bahrain. Banks and Bank Systems, 12(4), 4-16. doi:10.21511/bbs.12(4).2017.01 }\end{array}$ \\
\hline DOI & http://dx.doi.org/10.21511/bbs.12(4).2017.01 \\
\hline RELEASED ON & Tuesday, 21 November 2017 \\
\hline RECEIVED ON & Friday, 21 July 2017 \\
\hline ACCEPTED ON & Friday, 15 September 2017 \\
\hline & $(\mathrm{cc}) \overline{\mathrm{EY}}$ \\
\hline LICENSE & $\begin{array}{l}\text { This work is licensed under a Creative Commons Attribution } 4.0 \text { International } \\
\text { License }\end{array}$ \\
\hline JOURNAL & "Banks and Bank Systems" \\
\hline ISSN PRINT & $1816-7403$ \\
\hline ISSN ONLINE & $1991-7074$ \\
\hline PUBLISHER & LLC "Consulting Publishing Company "Business Perspectives" \\
\hline FOUNDER & LLC "Consulting Publishing Company "Business Perspectives" \\
\hline \multirow[b]{2}{*}{ NUMBER OF REFERENCES } & $\begin{array}{l}\text { ニ-: } \\
\text { ニ-:- }\end{array}$ \\
\hline & NUMBER OF FIGURES \\
\hline 14 & 7 \\
\hline
\end{tabular}

(c) The author(s) 2023. This publication is an open access article. 


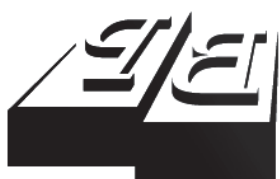

BUSINESS PERSPECTIVES

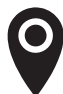

LLC "CPC "Business Perspectives" Hryhorii Skovoroda lane, 10, Sumy, 40022, Ukraine

www.businessperspectives.org

Received on: $21^{\text {st }}$ of July, 2017 Accepted on: $15^{\text {th }}$ of September, 2017

(C) Iqbal Thonse Hawaldar, Babitha Rohit, Prakash Pinto, Rajesha T. M., 2017

Iqbal Thonse Hawaldar, Associate Professor, College of Business Administration \& Assistant to the President for Accreditation and Quality Assurance, Kingdom University, Bahrain.

Babitha Rohit, Assistant Professor, Department of Business Administration, St. Joseph Engineering College, Mangalore, Karnataka, India.

Prakash Pinto, Professor and Dean, Department of Business Administration, St. Joseph Engineering College, Mangalore, Karnataka, India.

Rajesha T M, Institutional Measurement Administrator, Accreditation and Quality Assurance Office, Kingdom University, Bahrain.

\section{(ㄷ)(ㄱ)}

This is an Open Access article, distributed under the terms of the Creative Commons Attribution 4.0 International license, which permits unrestricted re-use, distribution, and reproduction in any medium provided the original work is properly cited.
Iqbal Thonse Hawaldar (Bahrain), Babitha Rohit (India), Prakash Pinto (India),

Rajesha T. M. (Bahrain)

\section{THE IMPACT OF OIL PRICE CRISIS ON FINANCIAL PERFORMANCE OF COMMERCIAL BANKS IN BAHRAIN}

\begin{abstract}
Oil export is the major source of revenue for the countries in the Middle East. Their economies are sensitive to fluctuations in oil prices. The present study examines the impact of oil crisis on the performance of selected banks of Kingdom of Bahrain using profitability, efficiency, capital adequacy and liquidity ratios in the pre-crisis and crisis periods. The study reveals that there is no significant difference in the performance of banks in the pre-crisis and crisis period. The results indicate that there is a significant difference in the performance of conventional banks and Islamic banks in the pre-crisis period. However, there is no significant difference in the performance of conventional banks and Islamic banks during the crisis period.
\end{abstract}

\section{Keywords}

JEL Classification

oil crisis, bank performance, financial ratios

\section{INTRODUCTION}

The Gulf Cooperation Council (GCC) countries wealth has been possible due to the discovery and systematic production of oil in the 1960s. This has lead to the creation of ultramodern skylines of cities such as Dubai, Riyadh, and Doha. Oil and gas export revenues are the principal source of export income in the GCC, accounting for over $90 \%$ of total export revenues in countries such as Qatar and Kuwait, and well above 85\% in Saudi Arabia. With no income or corporate tax in these countries, oil and gas export revenues contribute over $90 \%$ of total government revenues.

The development of Bahrain's modern banking sector began nearly 100 years ago. Standard Chartered was the first bank to open its branch in Bahrain. The National Bank of Bahrain (NBB) was established in 1957. A large, highly skilled pool of financial workers, a regulatory structure whicht is both advanced and internationally well regarded, and a physical connection to Saudi Arabia, combined to make Bahrain an attractive destination for the global banking market. Bahrain's diverse banking industry is divided by the licensing regime into both conventional and Islamic retail and wholesale operations. Since the 1980s, Bahrain's banking sector has contained a growing number of Shariah-compliant institutions. Between 2000 and 2015, the market share of Islamic banks increased from $1.8 \%$ of total banking sector assets to $13.5 \%$. Conventional banking has long existed in the past, which provides financial product complied with interest rates. Islamic banking does not define money as commodity instead as a medium of exchange and store of value, so it cannot gain profit like conventional banking does. The financial sector contributes $17.2 \%$ to GDP of Bahrain. 


\section{LITERATURE REVIEW}

A decade of rising global oil prices peaked at a range of around \$100-110 per barrel between 2011 and mid-2014 (see Appendix). The collapse in oil prices since the summer of 2014 has raised concerns over the long-term stability of the GCC economies. Oil price decline is not a short-term phenomenon, and causal factors including continued oil market oversupply and weaker than expected demand growth imply that oil producers will need to deal with a lower oil price band for yet some more time. Oman and Bahrain's oil production is expected to last for 10-15 years. Kuwait, Qatar and Saudi Arabia are in a better position, with projected oil reserves of 80100 years based on current estimates.

Poghosyan and Hesse (2009) analyzed the relationship between oil price shocks and bank profitability using data on 145 banks in 11 oil-exporting Middle East and North Africa (MENA) countries for 1994-2008. The results indicated that oil price shocks have indirect effect on bank profitability, channeled through country-specific macroeconomic and institutional variables, while the direct effect is insignificant. Investment banks appear to be the most affected ones compared to Islamic and commercial banks.

Almasafir, Kim, and Alsamadi (2016) studied the performance of both Islamic and conventional banking during global financial crisis for the period 2005 to 2013 in Bahrain. They concluded that Islamic banking performs better than conventional banking during the crisis, but in the long run, the result is reversed due to conventional banking size of business.

Hawaldar, Lokesh, and Biso (2016a) analyzed the financial performance of retail and wholesale Islamic Banks operating in the Kingdom of Bahrain for the time period 2009-2013. The study found a negative relationship among asset utilization ratio with staff cost to income ratio, operational efficiency ratio and cost to income ratio of retail Islamic banks. For wholesale Islamic banks, there was a positive relationship among staff cost to income ratio, operational efficiency ratio and cost to income ratio.

Hawaldar, Pinto, and Lokesh (2016b) examined the financial performance of retail and whole- sale conventional banks in Bahrain covering a period of five years from 2009 to 2013. The results indicated that wholesale banks are more efficient than retail banks in terms of overall cost to income and asset utilization, whereas retail banks are more efficient than wholesale banks in staff cost to income and operations. Hawaldar et al. (2017a and 2017b) compare the financial performance of Islamic and conventional commercials banks in Bahrain. They found that both the banks have their own advantages and disadvantages. Overall, the financial performance of Islamic and conventional commercial banks in Bahrain are almost same in many aspects/ parameters.

Aloydani (2016) assessed the effect of the 20142015 oil price slump on the financial stability in the Gulf Cooperation Council (GCC) region. The study indicated that oil price, non-oil GDP, interest rate, stock prices, and housing prices are major determinants of non-performing loans (NPLs) across GCC banks and the overall financial stability in the region. A higher level of NPLs restricts banks' credit growth and can dampen economic growth in the GCC economies.

Ganguli (2016) analyzed the scope for economic and monetary union of GCC in the backdrop of oil crisis. The paper concluded that GCC countries are similar in terms of their structural and economic fundamentals. Yet fiscal vulnerabilities of these economies to oil price shocks create potential concerns during low oil prices.

Khandelwal, Miyajima, and Santos (2016) demonstrated the existence of oil macro-financial linkages in the GCC countries. The econometric analysis confirmed that oil prices and economic activity significantly affect bank asset quality. It also identified feedback loops between oil price movements, bank balance sheets and asset prices in the GCC.

\subsection{Need for the study}

The present study contributes to the literature by analyzing the impact of oil crisis on the performance of banks in the Kingdom of Bahrain. It classifies the impact based on pre-crisis and during crisis period. It also compares the impact of the event on conventional banks and Islamic banks. 


\subsection{Objectives of the study}

1. To examine the profitability, efficiency, capital adequacy and liquidity ratios of selected banks in the pre-crisis and crisis periods.

2. To compare the performance of conventional banks and Islamic banks in the pre-crisis period and during crisis.

\subsection{Hypotheses for the study}

H1: There is a significant difference in the financial ratios in the pre-crisis and crisis period.

H2: There is a significant difference in the performance of conventional banks and Islamic banks in the pre-crisis period.

H3: There is a significant difference in the performance of conventional banks and Islamic banks during crisis.

\section{METHODOLOGY}

The study uses ratios to measure the performance of selected banks. Profitability is measured by Return on Assets, Return on Equity, operating profit to total assets, net income to total assets and net interest income to total income ratios. Cost to income ratio is used to measure efficiency of banks. Risk assets ratio and loans to total assets ratio are used as indicators of capital adequacy. Liquidity of banks is assessed using customer deposits to total assets and loans to deposits ratios. Descriptive statistics is used to examine the trend of variables in the pre-crisis and during crisis. Single-factor ANOVA and t-tests are used to study the impact of the oil crisis on the performance of selected banks.

\section{DATA INTERPRETATION}

\subsection{Performance of banks in pre-crisis period}

Table 1 presents the descriptive statistics for the variables during pre-crisis period. Return on Assets (ROA) is a measure of the efficiency of a company in generating returns from its assets, without being affected by management financing decisions. A high ROA is a sign of solid financial and operational performance. The highest mean Return on Assets (ROA) is recorded by NBB with value of 1.91, while the lowest ROA is recorded by $\mathrm{BIB}$. The standard deviation value indicates a high ratio for BIB signaling large variability in its returns on asset. The lowest standard deviation is of NBB indicating stability in generating profits from its assets.

ROE reveals efficiency of usage of shareholders' funds. NBB has the highest mean ROE of 15.89 indicating the efficient use of shareholders' funds. BBK and AUB have ROE of 14.77 and 13.03, respectively. BDB has the lowest ROE of -1.60. BIB records the highest standard deviation of 29.76, while AUB has a low of 0.35 .

Operating profit to total assets measures the profitability of the business from the perspective of managerial efficiency. This ratio is the highest for $\mathrm{BIB}$ with a value of 4.87 followed by KFH with ratio of 4.17. The banks have a low standard deviation ranging from 0.10 to 0.81 .

The performance of banks is largely dependent on the net interest income. a high ratio of net interest income to total assets indicates financial strength. aib has the highest net interest income to total assets ratio at 4.85 followed by BIB at 4.17. the lowest ratio is recorded by AUB. another measure of net interest income is the net interest income to total income ratio. AIB records the highest mean Net Interest Income to Total Income ratio of 201.68 with standard deviation of 19.78 , followed by AUB with a mean value 165.06 and standard deviation of 36.50 . It can be observed that there is large variation in the net interest income of AIB and AUB.

Cost to income ratio measures operating expense as a percentage of operating income. AIB records a high cost to income ratio of 93.50 indicating low efficiency and productivity. AUB has the lowest ratio of 31.30 signifying high efficiency and productivity. It can also be observed that NBB also records a low ratio of 32.40 . This indicates consistent efficiency in the performance of variables like ROA and ROE of NBB. 
Table 1. Performance of banks (pre-crisis) - descriptive statistics of variables

Source: authors' calculations.

\begin{tabular}{|c|c|c|c|c|c|c|c|c|c|}
\hline \multirow{2}{*}{\multicolumn{2}{|c|}{$\begin{array}{c}\text { Dependent and independent } \\
\text { variables }\end{array}$}} & \multicolumn{7}{|c|}{ Pre-crisis } & \multirow{2}{*}{ Mean } \\
\hline & & AUB & BBK & NBB & BIB & BDB & KFH & AIB & \\
\hline \multicolumn{10}{|c|}{ Profitability } \\
\hline \multirow{4}{*}{ ROA } & Mean & 1.26 & 1.36 & 1.91 & -1.86 & -0.70 & 0.48 & 1.30 & 0.54 \\
\hline & Min & 1.19 & 1.20 & 1.88 & -4.33 & -2.05 & 0.38 & 1.30 & -0.06 \\
\hline & $\operatorname{Max}$ & 1.30 & 1.46 & 1.96 & 0.70 & 0.16 & 0.65 & 1.30 & 1.08 \\
\hline & Std. D. & 0.06 & 0.14 & 0.04 & 2.52 & 1.18 & 0.15 & 0.00 & 0.59 \\
\hline \multirow{4}{*}{ ROE } & Mean & 13.03 & 14.77 & 15.89 & 11.19 & -1.60 & 2.03 & 12.43 & 9.68 \\
\hline & Min & 12.70 & 13.40 & 15.06 & -17.00 & -4.71 & 1.53 & 11.70 & 4.67 \\
\hline & $\operatorname{Max}$ & 13.40 & 16.34 & 16.60 & 42.31 & 0.39 & 2.56 & 13.10 & 14.96 \\
\hline & Std. D. & 0.35 & 1.48 & 0.78 & 29.76 & 2.73 & 0.52 & 0.70 & 5.19 \\
\hline \multirow{4}{*}{$\begin{array}{l}\text { Operating profit } \\
\text { to total assets }\end{array}$} & Mean & 1.89 & 3.16 & 3.23 & 4.87 & 1.01 & 4.17 & 2.75 & 3.01 \\
\hline & Min & 1.79 & 2.90 & 3.08 & 4.56 & 0.71 & 3.39 & 2.67 & 2.73 \\
\hline & $\operatorname{Max}$ & 1.98 & 3.49 & 3.35 & 5.16 & 1.23 & 5.01 & 2.88 & 3.30 \\
\hline & Std. D. & 0.10 & 0.30 & 0.14 & 0.30 & 0.27 & 0.81 & 0.12 & 0.29 \\
\hline \multirow{4}{*}{$\begin{array}{l}\text { Net interest } \\
\text { income } \\
\text { to total assets }\end{array}$} & Mean & 1.97 & 2.13 & 2.67 & 4.17 & 2.88 & 3.62 & 4.85 & 3.19 \\
\hline & Min & 1.79 & 1.62 & 2.32 & 3.68 & 1.10 & 2.91 & 2.69 & 2.30 \\
\hline & Max & 2.13 & 2.90 & 3.35 & 4.89 & 4.20 & 5.01 & 5.99 & 4.07 \\
\hline & Std. D. & 0.17 & 0.68 & 0.59 & 0.64 & 1.60 & 1.20 & 1.87 & 0.96 \\
\hline \multirow{4}{*}{$\begin{array}{l}\text { Net interest } \\
\text { income to total } \\
\text { income }\end{array}$} & Mean & 165.06 & 59.16 & 70.48 & 117.28 & 76.45 & 114.26 & 201.68 & 114.91 \\
\hline & Min & 123.11 & 55.68 & 69.28 & 101.34 & 74.45 & 89.30 & 179.51 & 98.95 \\
\hline & $\operatorname{Max}$ & 189.56 & 61.27 & 71.49 & 125.30 & 79.99 & 133.17 & 217.53 & 125.47 \\
\hline & Std. D. & 36.50 & 3.04 & 1.12 & 13.80 & 3.07 & 22.55 & 19.78 & 14.27 \\
\hline \multicolumn{10}{|c|}{ Efficiency } \\
\hline \multirow{4}{*}{ Cost to income ratio } & Mean & 31.30 & 46.75 & 32.40 & 69.49 & 81.33 & 34.77 & 93.50 & 55.65 \\
\hline & $\operatorname{Min}$ & 30.00 & 45.30 & 31.57 & 53.44 & 79.00 & 29.00 & 91.00 & 51.33 \\
\hline & $\operatorname{Max}$ & 32.40 & 48.41 & 33.20 & 80.14 & 84.00 & 41.50 & 98.40 & 59.72 \\
\hline & Std. D. & 1.21 & 1.57 & 0.82 & 14.15 & 2.52 & 6.31 & 4.24 & 4.40 \\
\hline \multicolumn{10}{|c|}{ Capital adequacy } \\
\hline \multirow{4}{*}{ Risk assets ratio } & Mean & 15.93 & 14.82 & 28.04 & 12.93 & 44.00 & 24.63 & 22.40 & 23.25 \\
\hline & Min & 15.60 & 14.29 & 25.05 & 12.31 & 40.00 & 22.90 & 20.90 & 21.58 \\
\hline & $\operatorname{Max}$ & 16.20 & 15.33 & 31.22 & 13.55 & 48.00 & 26.20 & 24.90 & 25.06 \\
\hline & Std. D. & 0.31 & 0.52 & 3.09 & 0.88 & 4.00 & 1.66 & 2.18 & 1.80 \\
\hline \multirow{4}{*}{$\begin{array}{l}\text { Loans to total assets } \\
\text { ratio }\end{array}$} & Mean & 53.72 & 49.74 & 35.14 & 48.18 & 67.33 & 38.30 & 43.56 & 48.00 \\
\hline & Min & 53.00 & 48.23 & 31.26 & 46.72 & 60.00 & 37.44 & 40.63 & 45.33 \\
\hline & $\operatorname{Max}$ & 54.70 & 50.89 & 40.70 & 49.81 & 71.00 & 39.10 & 45.86 & 50.29 \\
\hline & Std. D. & 0.88 & 1.37 & 4.94 & 1.55 & 6.35 & 0.83 & 2.67 & 2.66 \\
\hline \multicolumn{10}{|c|}{ Liquidity } \\
\hline \multirow{4}{*}{$\begin{array}{l}\text { Customer deposits } \\
\text { to total assets }\end{array}$} & Mean & 63.24 & 72.95 & 77.95 & 66.59 & 29.45 & 51.97 & 84.98 & 63.88 \\
\hline & Min & 61.03 & 70.94 & 75.79 & 63.08 & 25.53 & 50.17 & 79.14 & 60.81 \\
\hline & $\operatorname{Max}$ & 67.46 & 75.08 & 79.77 & 68.87 & 33.67 & 53.04 & 93.68 & 67.37 \\
\hline & Std. D. & 3.66 & 2.07 & 2.01 & 3.09 & 4.08 & 1.57 & 7.68 & 3.45 \\
\hline \multirow{4}{*}{$\begin{array}{l}\text { Loans } \\
\text { to deposits ratio }\end{array}$} & Mean & 84.33 & 68.19 & 45.00 & 85.84 & 2.14 & 73.68 & 51.45 & 58.66 \\
\hline & Min & 78.56 & 67.77 & 41.25 & 70.80 & 2.10 & 72.29 & 47.16 & 54.28 \\
\hline & $\operatorname{Max}$ & 89.34 & 68.81 & 51.01 & 114.40 & 2.19 & 74.56 & 55.84 & 65.16 \\
\hline & Std. D. & 5.43 & 0.55 & 5.26 & 24.75 & 0.05 & 1.22 & 4.34 & 5.94 \\
\hline
\end{tabular}


Capital adequacy refers to the adequacy of capital resources of a bank in relation to the risks associated with its operations. Risk assets ratio is the ratio of banks capital to its risk weighted assets. It protects the bank's depositors and other lenders. A high capital adequacy ratio for a bank is considered safe and it is likely to meet financial obligations. The highest average risk assets ratio is recorded for BDB (44) while the lowest ratio is of BIB. Banks AUB and BBK also have low risk assets ratio.

Loan to total assets ratio measures the total loans outstanding as a percentage of total assets. The higher ratio indicates a bank is loaned up and its liquidity is low. The higher the ratio, the more risky a bank may be to higher defaults. BDB has the highest ratio at 67.33 , indicating that its liquidity is very low. For other banks, the loan to total assets ratio ranges from 35.14 to 53.72 . BDB also records a maximum standard deviation of 6.35 .

Liquidity of banks can be assessed with customer deposits to total assets ratio and loan to deposits ratio. Customer deposits to total assets ratio is very high for bank AIB (84.98). This is a positive signal for the bank, as it is able to attract deposits from customers. The lowest ratio is recorded for $\mathrm{BDB}$ at 29.45. For other banks ratio ranges from 51.97 to 77.95 .

The loan to deposit ratio assesses a bank's liquidity by dividing the bank's total loans by its total deposits. If the ratio is too high, it means that the bank may not have enough liquidity to cover any unforeseen fund requirements, and conversely, if the ratio is too low, the bank may not be earning as much as it could be. In the Table above, it is revealed that banks BIB and AUB record the highest loan to deposits ratio. Bank BDB has a low ratio of 2.14, which is a clear indication of low earnings.

\subsection{Performance of banks during crisis period}

The mean ROA of the banks during the crisis increased to 1.89 from 0.54 reported during the precrisis period. Banks BIB and BDB, which recorded

Table 2. Performance of banks (during crisis) - descriptive statistics of variables

Source: authors' calculations.

\begin{tabular}{|c|c|c|c|c|c|c|c|c|c|}
\hline \multirow{2}{*}{\multicolumn{2}{|c|}{$\begin{array}{l}\text { Dependent and } \\
\text { independent variables }\end{array}$}} & \multicolumn{7}{|c|}{ During crisis } & \multirow{2}{*}{ Mean } \\
\hline & & AUB & BBK & NBB & BIB & BDB & KFH & AIB & \\
\hline \multicolumn{10}{|c|}{ Profitability } \\
\hline \multirow{4}{*}{$\mathrm{ROA}$} & Mean & 2.15 & 2.18 & 1.94 & 2.07 & 1.66 & 1.12 & 2.08 & 1.89 \\
\hline & Min & 1.60 & 1.44 & 1.93 & 1.00 & 0.42 & 0.34 & 1.20 & 1.13 \\
\hline & Max & 3.16 & 3.60 & 1.95 & 3.99 & 3.99 & 2.30 & 3.75 & 3.25 \\
\hline & Std. D. & 0.87 & 1.23 & 0.01 & 1.67 & 2.02 & 1.04 & 1.44 & 1.18 \\
\hline \multirow{4}{*}{ ROE } & Mean & 17.67 & 18.96 & 14.75 & 19.82 & 4.03 & 4.79 & 15.56 & 13.65 \\
\hline & Min & 15.20 & 13.93 & 14.42 & 11.80 & 0.96 & 1.40 & 13.60 & 10.19 \\
\hline & Max & 21.81 & 28.15 & 14.94 & 35.78 & 9.78 & 10.03 & 19.39 & 19.98 \\
\hline & Std. D. & 3.61 & 7.97 & 0.28 & 13.82 & 4.98 & 4.60 & 3.31 & 5.51 \\
\hline \multirow{4}{*}{$\begin{array}{l}\text { Operating } \\
\text { profit to total } \\
\text { assets }\end{array}$} & Mean & 2.65 & 3.92 & 2.79 & 4.18 & 1.30 & 5.15 & 2.25 & 3.18 \\
\hline & Min & 2.10 & 3.60 & 1.95 & 2.02 & 0.48 & 0.27 & 0.96 & 1.63 \\
\hline & Max & 3.66 & 4.38 & 3.26 & 5.71 & 2.65 & 8.48 & 3.09 & 4.46 \\
\hline & Std. D. & 0.88 & 0.41 & 0.73 & 1.93 & 1.18 & 4.32 & 1.14 & 1.51 \\
\hline \multirow{4}{*}{$\begin{array}{l}\text { Net interest } \\
\text { income to } \\
\text { total assets }\end{array}$} & Mean & 2.44 & 2.42 & 2.13 & 3.12 & 3.19 & 2.57 & 4.18 & 2.87 \\
\hline & Min & 2.28 & 2.31 & 1.98 & 2.74 & 2.98 & 2.48 & 3.98 & 2.68 \\
\hline & Max & 2.64 & 2.63 & 2.22 & 3.35 & 3.44 & 2.70 & 4.30 & 3.04 \\
\hline & Std. D. & 0.18 & 0.18 & 0.13 & 0.33 & 0.23 & 0.12 & 0.18 & 0.19 \\
\hline \multirow{4}{*}{$\begin{array}{l}\text { Net interest } \\
\text { income to } \\
\text { total income }\end{array}$} & Mean & 147.70 & 61.92 & 65.30 & 47.10 & 62.24 & 54.56 & 140.25 & 82.73 \\
\hline & Min & 133.28 & 60.02 & 63.05 & 8.70 & 53.55 & 37.02 & 134.38 & 70.00 \\
\hline & Max & 158.18 & 64.29 & 66.79 & 76.71 & 74.76 & 64.42 & 148.34 & 93.36 \\
\hline & Std. D. & 12.91 & 2.17 & 1.98 & 34.85 & 11.11 & 15.23 & 7.24 & 12.21 \\
\hline
\end{tabular}


Table 2 (cont). Performance of banks (during crisis) - descriptive statistics of variables

\begin{tabular}{|c|c|c|c|c|c|c|c|c|c|}
\hline \multirow{2}{*}{\multicolumn{2}{|c|}{$\begin{array}{c}\text { Dependent and } \\
\text { independent variables }\end{array}$}} & \multicolumn{7}{|c|}{ During crisis } & \multirow{2}{*}{ Mean } \\
\hline & & AUB & BBK & NBB & BIB & BDB & KFH & AIB & \\
\hline \multicolumn{10}{|c|}{ Efficiency } \\
\hline \multirow{4}{*}{$\begin{array}{l}\text { Cost to } \\
\text { income ratio }\end{array}$} & Mean & 29.93 & 45.74 & 33.27 & 54.41 & 77.15 & 32.99 & 74.19 & 49.67 \\
\hline & Min & 28.30 & 39.33 & 31.89 & 51.68 & 64.00 & 16.02 & 41.36 & 38.94 \\
\hline & $\operatorname{Max}$ & 32.29 & 56.75 & 35.19 & 56.44 & 86.00 & 57.12 & 92.70 & 59.50 \\
\hline & Std. D. & 2.09 & 9.58 & 1.72 & 2.45 & 11.62 & 21.47 & 28.51 & 11.06 \\
\hline \multicolumn{10}{|c|}{ Capital adequacy } \\
\hline \multirow{4}{*}{$\begin{array}{l}\text { Risk assets } \\
\text { ratio }\end{array}$} & Mean & 16.43 & 16.33 & 33.22 & 17.88 & 39.86 & 17.40 & 20.13 & 23.04 \\
\hline & Min & 15.50 & 14.87 & 29.99 & 15.61 & 37.00 & 14.60 & 18.70 & 20.90 \\
\hline & Max & 17.10 & 18.48 & 35.39 & 20.30 & 44.00 & 20.10 & 21.60 & 25.28 \\
\hline & Std. D. & 0.83 & 1.90 & 2.85 & 2.35 & 3.67 & 2.75 & 1.45 & 2.26 \\
\hline \multirow{4}{*}{$\begin{array}{l}\text { Loans to total } \\
\text { assets ratio }\end{array}$} & Mean & 65.90 & 62.78 & 49.88 & 48.39 & 62.07 & 41.19 & 49.12 & 54.19 \\
\hline & Min & 55.21 & 48.41 & 28.52 & 26.04 & 59.21 & 36.70 & 43.95 & 42.58 \\
\hline & Max & 85.50 & 87.19 & 86.07 & 60.86 & 64.00 & 49.07 & 55.63 & 69.76 \\
\hline & Std. D. & 17.00 & 21.25 & 31.51 & 19.40 & 2.53 & 6.85 & 5.96 & 14.93 \\
\hline \multicolumn{10}{|c|}{ Liquidity } \\
\hline \multirow{4}{*}{$\begin{array}{l}\text { Customer } \\
\text { deposits to } \\
\text { total assets }\end{array}$} & Mean & 69.08 & 70.14 & 74.58 & 71.49 & 25.91 & 50.35 & 79.56 & 63.02 \\
\hline & Min & 68.79 & 67.35 & 70.15 & 64.74 & 21.98 & 45.72 & 77.40 & 59.45 \\
\hline & Max & 69.29 & 72.49 & 78.69 & 77.50 & 30.46 & 57.89 & 81.42 & 66.82 \\
\hline & Std. D. & 0.26 & 2.60 & 4.28 & 6.41 & 4.27 & 6.58 & 2.03 & 3.78 \\
\hline \multirow{4}{*}{$\begin{array}{l}\text { Loans to } \\
\text { deposits ratio }\end{array}$} & Mean & 82.79 & 70.78 & 44.15 & 77.47 & 2.59 & 74.11 & 59.35 & 58.75 \\
\hline & Min & 80.26 & 66.78 & 36.24 & 72.48 & 2.37 & 65.15 & 56.78 & 54.29 \\
\hline & Max & 85.73 & 74.71 & 49.41 & 81.46 & 2.87 & 79.43 & 61.48 & 62.16 \\
\hline & Std. D. & 2.76 & 3.97 & 6.98 & 4.57 & 0.26 & 7.81 & 2.38 & 4.10 \\
\hline
\end{tabular}

negative ROA in the pre-crisis period, realized positive ROA of 2.07 and 1.66 , respectively.

BIB records high mean ROE of 19.82 and standard deviation of 13.82 during crisis. All the banks except NBB have improved the ROE during crisis. NBB records a marginal decrease in its ROE from pre-crisis to crisis period.

Operating profit to total assets ratio is highest for $\mathrm{KFH}$ followed by BIB. This points to continued managerial efficiency of these banks in the crisis period. The other banks show a moderate increase in this ratio.

Bank AIB continues to be in good position in the crisis period. It's net income to total assets and net interest income to total assets ratios are high compared to the other banks. It is interesting to observe that BIB's net interest income to total assets ratio has declined from 117.28 to 47.10 from precrisis to crisis period with a standard deviation of 34.85. This reveals that the bank was unable to sustain its interest income during the crisis period.

AUB continued with low cost to income ratio leadership in the crisis period. The other banks showed marginal decrease in its ratio in the crisis period. An interesting observation is of AIB, which showed a substantial reduction in its cost to income ratio in the crisis period.

Capital adequacy of bank is measured by risk assets ratio and loan to total assets ratio. AUB, BBK, NBB and BIB improved its risk assets ratio from the pre-crisis period. BDB has the highest risk assets ratio although it is lower than the pre-crisis period. The loan to total assets ratio of $\mathrm{BDB}, \mathrm{AUB}$ and $\mathrm{BBK}$ are high indicating high-risk assets in the crisis period. The customer deposits to total assets ratio continues to be high for banks AIB, $\mathrm{NBB}$ and BIB during the crisis period. The loan to deposits ratio is high for bank BIB and low for bank BDB. 


\subsection{Performance of conventional and Islamic banks during pre- crisis and crisis period}

Table 3 presents the ratios of conventional banks and Islamic banks during pre-crisis and crisis period. profitability indicators like ROA, ROE, operating profit to total assets and net interest income to total assets for conventional banks increased from pre-crisis to crisis period. however, net interest income to total income dropped from 102.24 to 82.37 in the crisis period. ROA and ROE of Islamic banks rose substantially in the crisis period. ratios such as operating profit to total assets, net interest income to total assets and net interest income to total income recorded a decline in the crisis period.
There is a marginal decrease in the cost to income ratio of conventional banks, while there is steep decline in the ratio of Islamic banks. The risk assets ratio of conventional banks reflects consistency during both the periods. There is a small decrease in the risk assets ratio of Islamic banks in the crisis period. The proportion of loan to total assets of conventional banks increased during the crisis period. The Islamic banks recorded a marginal increase in the loan to total assets ratio during the same period. Conventional banks lent more loans during the crisis period.

An analysis of the liquidity indicators reveals that liquidity of banks remained consistent irrespective of the crisis. The oil crisis did not have much impact on the liquidity of banks.

Table 3. Comparative performance - pre crisis and during crisis

Source: authors' calculations.

\begin{tabular}{|c|c|c|c|c|c|}
\hline \multirow{2}{*}{\multicolumn{2}{|c|}{$\begin{array}{l}\text { Dependent and } \\
\text { independent variables }\end{array}$}} & \multicolumn{2}{|c|}{ Conventional banks } & \multicolumn{2}{|c|}{ Islamic banks } \\
\hline & & Pre-crisis & During crisis & Pre-crisis & During crisis \\
\hline \multicolumn{6}{|c|}{ Profitability } \\
\hline \multirow{4}{*}{$\mathrm{ROA}$} & Mean & 1.25 & 1.85 & -0.42 & 1.94 \\
\hline & Min & 0.38 & 0.34 & -4.33 & 0.42 \\
\hline & Max & 1.96 & 3.60 & 0.70 & 3.99 \\
\hline & Std. D. & 0.54 & 0.90 & 1.87 & 1.67 \\
\hline \multirow{4}{*}{ ROE } & Mean & 11.43 & 14.04 & 7.34 & 13.14 \\
\hline & Min & 1.53 & 1.40 & -17.00 & 0.96 \\
\hline & $\operatorname{Max}$ & 16.60 & 28.15 & 42.31 & 35.78 \\
\hline & Std. D. & 5.82 & 7.17 & 16.39 & 11.62 \\
\hline \multirow{4}{*}{$\begin{array}{l}\text { Operating } \\
\text { profit to total } \\
\text { assets }\end{array}$} & Mean & 3.11 & 3.63 & 2.88 & 2.58 \\
\hline & Min & 1.79 & 0.27 & 0.71 & 0.48 \\
\hline & Max & 5.01 & 8.48 & 5.16 & 4.82 \\
\hline & Std. D. & 0.93 & 2.18 & 2.13 & 1.98 \\
\hline \multirow{4}{*}{$\begin{array}{l}\text { Net interest } \\
\text { income to } \\
\text { total assets }\end{array}$} & Mean & 2.27 & 2.39 & 4.40 & 3.50 \\
\hline & Min & 1.88 & 1.98 & 3.35 & 2.98 \\
\hline & Max & 2.91 & 2.70 & 5.99 & 3.98 \\
\hline & Std. D. & 0.33 & 0.21 & 0.98 & 0.51 \\
\hline \multirow{4}{*}{$\begin{array}{l}\text { Net interest } \\
\text { income to } \\
\text { total income }\end{array}$} & Mean & 102.24 & 82.37 & 131.80 & 83.20 \\
\hline & Min & 55.68 & 37.02 & 74.45 & 8.70 \\
\hline & Max & 189.56 & 158.18 & 125.30 & 76.71 \\
\hline & Std. D. & 47.26 & 40.53 & 24.09 & 24.57 \\
\hline \multicolumn{6}{|c|}{ Efficiency } \\
\hline \multirow{4}{*}{$\begin{array}{l}\text { Cost to } \\
\text { income ratio }\end{array}$} & Mean & 36.30 & 35.48 & 81.44 & 68.58 \\
\hline & Min & 29.00 & 16.02 & 53.44 & 41.36 \\
\hline & Max & 48.41 & 57.12 & 98.40 & 92.70 \\
\hline & Std. D. & 7.03 & 11.91 & 12.81 & 18.79 \\
\hline
\end{tabular}


Table 3 (cont). Comparative performance - pre crisis and during crisis

\begin{tabular}{|c|c|c|c|c|c|}
\hline \multirow{2}{*}{\multicolumn{2}{|c|}{$\begin{array}{c}\text { Dependent and } \\
\text { independent variables }\end{array}$}} & \multicolumn{2}{|c|}{ Conventional banks } & \multicolumn{2}{|c|}{ Islamic banks } \\
\hline & & Pre-crisis & During crisis & Pre-crisis & During crisis \\
\hline \multicolumn{6}{|c|}{ Capital adequacy } \\
\hline \multirow{4}{*}{$\begin{array}{l}\text { Risk assets } \\
\text { ratio }\end{array}$} & Mean & 20.86 & 20.85 & 28.13 & 25.96 \\
\hline & Min & 14.29 & 14.60 & 12.31 & 15.61 \\
\hline & Max & 31.22 & 35.39 & 48.00 & 44.00 \\
\hline & Std. D. & 6.07 & 7.72 & 13.93 & 10.72 \\
\hline \multirow{4}{*}{$\begin{array}{l}\text { Loans to total } \\
\text { assets ratio }\end{array}$} & Mean & 44.23 & 54.94 & 53.02 & 53.19 \\
\hline & Min & 31.26 & 28.52 & 40.63 & 26.04 \\
\hline & Max & 54.70 & 87.19 & 71.00 & 64.00 \\
\hline & Std. D. & 8.37 & 20.78 & 11.47 & 12.21 \\
\hline \multicolumn{6}{|c|}{ Liquidity } \\
\hline \multirow{4}{*}{$\begin{array}{l}\text { Customer } \\
\text { deposits to } \\
\text { total assets }\end{array}$} & Mean & 66.53 & 66.04 & 60.34 & 58.99 \\
\hline & Min & 50.17 & 45.72 & 25.53 & 21.98 \\
\hline & Max & 79.77 & 78.69 & 93.68 & 81.42 \\
\hline & Std. D. & 10.58 & 10.32 & 24.93 & 25.37 \\
\hline \multirow{4}{*}{$\begin{array}{l}\text { Loans to } \\
\text { deposits ratio }\end{array}$} & Mean & 67.80 & 67.96 & 46.47 & 46.47 \\
\hline & Min & 41.25 & 36.24 & 2.10 & 2.37 \\
\hline & Max & 89.34 & 85.73 & 114.40 & 81.46 \\
\hline & Std. D. & 15.38 & 15.85 & 38.54 & 33.93 \\
\hline
\end{tabular}

\section{SINGLE FACTOR ANOVA ON ALL THE BANKS}

Table 4 presents the results of ANOVA in the precrisis and crisis period. In the pre-crisis period, all performance indicators except ROE are signifi- cant as the p-value is less than 0.05. During the crisis period, net interest income to total assets ratio, net interest income to total income, risk assets ratio, customer deposits to total assets ratio, loan to deposits ratio and cost to income ratio are significant as the $\mathrm{p}$ value is less than 0.05 .

Table 4. Single factor ANOVA on all the banks

Source: authors' calculations.

\begin{tabular}{|c|c|c|c|c|}
\hline \multirow{2}{*}{ Variables } & \multicolumn{2}{|c|}{ Pre-crisis } & \multicolumn{2}{|c|}{ During crisis } \\
\hline & F statistic & P-value & F statistic & P-value \\
\hline \multicolumn{5}{|c|}{ Profitability } \\
\hline $\mathrm{ROA}$ & 4.9462 & 0.0065 & 0.2458 & 0.9531 \\
\hline $\mathrm{ROE}$ & 1.0588 & 0.4309 & 2.7841 & 0.0537 \\
\hline Operating profit to total assets & 37.3306 & 0.0000 & 1.3541 & 0.2984 \\
\hline Net interest income to total assets & 46.6280 & 0.0000 & 34.9388 & 0.0000 \\
\hline Net interest income to total income & 23.8003 & 0.0000 & 20.9334 & 0.0000 \\
\hline \multicolumn{5}{|c|}{ Capital adequacy } \\
\hline Risk assets ratio & 70.9333 & 0.0000 & 46.1439 & 0.0000 \\
\hline Loans to total assets ratio & 31.0690 & 0.0000 & 0.8274 & 0.5677 \\
\hline \multicolumn{5}{|c|}{ Liquidity } \\
\hline Customer deposits to total assets & 65.9893 & 0.0000 & 55.8031 & 0.0000 \\
\hline Loans to deposits ratio & 26.1082 & 0.0000 & 102.5691 & 0.0000 \\
\hline \multicolumn{5}{|c|}{ Efficiency } \\
\hline Cost to income ratio & 51.2087 & 0.0000 & 5.3916 & 0.0045 \\
\hline
\end{tabular}

Note: F-critical value is 2.8477 


\subsection{Single factor ANOVA on conventional and Islamic banks}

A comparison of conventional and Islamic banks is made in Table 5. All the profitability indicators for Conventional banks are significant at 0.05 level in the pre-crisis period. Only three profitability indicators show significance at 0.05 level for Islamic banks. During crisis, $\mathrm{ROE}$, net interest income to total assets ratio and net interest income to total income ratio is significant for conventional banks while net in- terest income to total assets ratio and net interest income to total income ratio is significant for Islamic banks.

Capital adequacy indicators are significant at 0.05 level for conventional and Islamic banks in the pre-crisis period. During crisis, risk assets ratio is significant for both categories of banks. Liquidity indicators are significant at 0.05 level for conventional and Islamic banks in the pre-crisis and crisis period. The cost to income ratio is not significant at 0.05 level during crisis.

Table 5. Single factor ANOVA on conventional \& Islamic banks

Source: authors' calculations.

\begin{tabular}{|c|c|c|c|c|c|}
\hline \multirow{2}{*}{\multicolumn{2}{|c|}{ Variables }} & \multicolumn{2}{|c|}{ Pre-crisis } & \multicolumn{2}{|c|}{ During crisis } \\
\hline & & F statistic & P-value & F statistic & P-value \\
\hline \multicolumn{6}{|c|}{ Profitability } \\
\hline \multirow{2}{*}{ ROA } & Conventional & 86.4435 & 0.0000 & 0.8758 & 0.4930 \\
\hline & Islamic & 2.9823 & 0.1261 & 0.0587 & 0.9436 \\
\hline \multirow{2}{*}{ ROE } & Conventional & 153.1396 & 0.0000 & 5.0447 & 0.0299 \\
\hline & Islamic & 0.6079 & 0.5749 & 2.6478 & 0.1499 \\
\hline \multirow{2}{*}{$\begin{array}{l}\text { Operating profit to } \\
\text { total assets }\end{array}$} & Conventional & 13.5206 & 0.0017 & 0.8086 & 0.5238 \\
\hline & Islamic & 189.7549 & 0.0000 & 3.0374 & 0.1227 \\
\hline \multirow{2}{*}{$\begin{array}{l}\text { Net interest income } \\
\text { to total assets }\end{array}$} & Conventional & 19.2548 & 0.0005 & 4.4097 & 0.0414 \\
\hline & Islamic & 13.4395 & 0.0061 & 16.1213 & 0.0039 \\
\hline \multirow{2}{*}{$\begin{array}{l}\text { Net interest income } \\
\text { to total income }\end{array}$} & Conventional & 15.0273 & 0.0012 & 56.4985 & 0.0000 \\
\hline & Islamic & 62.0771 & 0.0001 & 16.1761 & 0.0038 \\
\hline \multicolumn{6}{|c|}{ Capital adequacy } \\
\hline \multirow{2}{*}{ Risk assets ratio } & Conventional & 40.0162 & 0.0000 & 40.9351 & 0.0000 \\
\hline & Islamic & 107.5962 & 0.0000 & 62.3759 & 0.0001 \\
\hline \multirow{2}{*}{$\begin{array}{l}\text { Loans to total assets } \\
\text { ratio }\end{array}$} & Conventional & 34.3797 & 0.0001 & 0.8899 & 0.4867 \\
\hline & Islamic & 28.6783 & 0.0008 & 1.2744 & 0.3457 \\
\hline \multicolumn{6}{|c|}{ Liquidity } \\
\hline \multirow{2}{*}{$\begin{array}{l}\text { Customer deposits to } \\
\text { total assets }\end{array}$} & Conventional & 65.2716 & 0.0000 & 20.1595 & 0.0004 \\
\hline & Islamic & 84.6182 & 0.0000 & 118.6233 & 0.0000 \\
\hline \multirow{2}{*}{$\begin{array}{l}\text { Loans to deposits } \\
\text { ratio }\end{array}$} & Conventional & 56.2137 & 0.0000 & 25.0456 & 0.0002 \\
\hline & Islamic & 25.2400 & 0.0012 & 515.6653 & 0.0000 \\
\hline \multicolumn{6}{|c|}{ Efficiency } \\
\hline \multirow{2}{*}{ Cost to income ratio } & Conventional & 13.6880 & 0.0016 & 1.0516 & 0.4214 \\
\hline & Islamic & 5.7796 & 0.0399 & 1.4432 & 0.3078 \\
\hline
\end{tabular}

Note: F critical value for conventional banks: 4.0661; F critical value for Islamic banks: 5.1432. 


\section{RESULT OF T-TEST (ALL BANKS)}

Table 6 presents the results of $\mathrm{t}$-test of all banks. Mean ROA during the crisis is more than pre-crisis period. The results of the t-test records a p-value of 0.0370 (two tailed) at $5 \%$ level of significance. This indicates that there is a significant difference in the mean ROA of all the banks before the crisis and during the crisis.

The mean ROE is also substantially high during the crisis. The results of the two tailed $t$ test indicates that there is a significant difference in the mean ROE of all the banks before the crisis and during the crisis. From the above Table, it can be further concluded that there is no significant difference in the operating profit to total assets before the crisis and during the crisis. There is also no significant difference in the net interest income to total assets before the crisis and during the crisis. However, there is a significant difference in the net interest to total income before the crisis and during the crisis.

The capital adequacy ratios also do not show any significant difference in their mean values before the crisis and during the crisis. The change in the mean values of the liquidity ratios as measured by customer deposits to total assets and loan to deposits do not show any significant difference before the crisis and during the crisis. Similarly, the efficiency indicator as measured by cost to income ratio does not show significant difference in the pre-crisis and crisis period. The results of the paired t-test on all banks reveal that there is no significant difference in the performance of banks in the pre-crisis and crisis period (refer to $\mathrm{H}_{1}$ ).

Table 6. Result of t-test (all banks)

\begin{tabular}{|c|c|c|c|c|c|}
\hline \multirow[b]{2}{*}{ Variables } & \multicolumn{5}{|c|}{ Profitability } \\
\hline & ROA & ROE & $\begin{array}{l}\text { Operating } \\
\text { profit to total } \\
\text { assets }\end{array}$ & $\begin{array}{l}\text { Net interest } \\
\text { income to } \\
\text { total assets }\end{array}$ & $\begin{array}{c}\text { Net interest } \\
\text { income to } \\
\text { total income }\end{array}$ \\
\hline Mean-pre-crisis & 0.5357 & 9.6767 & 3.0105 & 3.1852 & 114.9105 \\
\hline Mean-during-crisis & 1.8862 & 13.6538 & 3.1781 & 2.8652 & 82.7252 \\
\hline t Stat & -2.6713 & -3.5319 & -0.6350 & 1.2823 & 2.7999 \\
\hline $\mathrm{P}(\mathrm{T}<=\mathrm{t})$ two-tail & 0.0370 & 0.0123 & 0.5488 & 0.2471 & 0.0312 \\
\hline t Critical two-tail & 2.4469 & 2.4469 & 2.4469 & 2.4469 & 2.4469 \\
\hline
\end{tabular}

Panel B

\begin{tabular}{|c|c|c|c|c|c|}
\hline \multirow[b]{2}{*}{ Variables } & \multicolumn{2}{|c|}{ Capital adequacy } & \multicolumn{2}{|c|}{ Liquidity } & \multirow{2}{*}{ 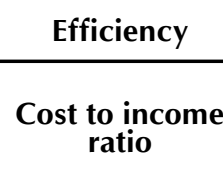 } \\
\hline & Risk assets ratio & $\begin{array}{l}\text { Loans to total } \\
\text { assets ratio }\end{array}$ & $\begin{array}{l}\text { Customer } \\
\text { deposits to } \\
\text { total assets }\end{array}$ & $\begin{array}{l}\text { Loans to } \\
\text { deposits ratio }\end{array}$ & \\
\hline Mean-pre-crisis & 23.2519 & 47.9971 & 63.8757 & 58.6610 & 55.6486 \\
\hline Mean-during-crisis & 23.0367 & 54.1895 & 63.0181 & 58.7490 & 49.6676 \\
\hline t Stat & 0.1232 & -2.1958 & 0.5145 & -0.0478 & 2.0032 \\
\hline $\mathrm{P}(\mathrm{T}<=\mathrm{t})$ two-tail & 0.9059 & 0.0705 & 0.6253 & 0.9634 & 0.0920 \\
\hline t Critical two-tail & 2.4469 & 2.4469 & 2.4469 & 2.4469 & 2.4469 \\
\hline
\end{tabular}




\section{1. t-test on conventional banks and Islamic banks}

The results of t-test on conventional and Islamic banks in the pre-crisis and crisis period have been presented in the Table 7 . The results show that there is no significant difference in the mean values of ROA, ROE and operating profit to total assets ratios of the conventional banks and Islamic banks. There is a significant difference in the net interest to total assets ratio between conventional and Islamic banks. In the pre-crisis period, there is a significant difference in the net interest to total income ratio of conventional banks and Islamic banks.

The t-test shows mixed results for capital adequacy, liquidity and efficiency measures. The

Table 7. t-test on conventional \& Islamic banks risk assets ratio shows significant difference between conventional banks and Islamic banks during the crisis period. There is a significant difference in the mean values of loan to total assets ratio between conventional and Islamic banks in the pre-crisis period. The customer deposits to total assets ratio is not significant in pre-crisis and during crisis. The loans to deposits ratio is significant in pre-crisis and during crisis period. The cost to income ratio is significant in the pre-crisis but not significant during crisis. The $t$ test results indicate that there is a significant difference in the performance of conventional banks and Islamic banks in the pre-crisis period (Refer $\mathrm{H}_{2}$ ). However, there is no significant difference in the performance of conventional banks and Islamic banks during the crisis period (refer to $\mathrm{H}_{3}$ ).

Source: authors' calculations.

Panel A

\begin{tabular}{|c|c|c|c|c|c|c|}
\hline & \multirow[b]{2}{*}{ Variables } & \multicolumn{5}{|c|}{ Profitability } \\
\hline & & ROA & ROE & $\begin{array}{c}\text { Operating } \\
\text { profit to } \\
\text { total assets }\end{array}$ & $\begin{array}{l}\text { Net interest } \\
\text { income to } \\
\text { total assets }\end{array}$ & $\begin{array}{l}\text { Net interest } \\
\text { income to } \\
\text { total income }\end{array}$ \\
\hline \multirow{5}{*}{ Pre-crisis } & Mean-conventional & 1.2542 & 11.4292 & 3.1108 & 2.2742 & 102.2408 \\
\hline & Mean-Islamic & -0.4222 & 7.3400 & 2.8767 & 4.4011 & 131.8033 \\
\hline & t Stat & 2.3978 & 0.8077 & 1.7399 & -13.1092 & -4.7716 \\
\hline & $\mathrm{P}(\mathrm{T}<=\mathrm{t})$ two-tail & 0.1387 & 0.5040 & 0.2240 & 0.0058 & 0.0412 \\
\hline & t Critical two-tail & 4.3027 & 4.3027 & 4.3027 & 4.3027 & 4.3027 \\
\hline \multirow{5}{*}{$\begin{array}{l}\text { During } \\
\text { crisis }\end{array}$} & Mean-conventional & 1.8492 & 14.0408 & 3.6267 & 2.3900 & 82.3708 \\
\hline & Mean-Islamic & 1.9356 & 13.1378 & 2.5800 & 3.4989 & 83.1978 \\
\hline & t Stat & -0.1613 & 0.4699 & 2.5636 & -24.1815 & -0.1344 \\
\hline & $\mathrm{P}(\mathrm{T}<=\mathrm{t})$ two-tail & 0.8867 & 0.6847 & 0.1244 & 0.0017 & 0.9054 \\
\hline & t Critical two-tail & 4.3027 & 4.3027 & 4.3027 & 4.3027 & 4.3027 \\
\hline \multicolumn{7}{|l|}{ Panel B } \\
\hline & & \multicolumn{2}{|c|}{ Capital adequacy } & \multicolumn{2}{|c|}{ Liquidity } & Efficiency \\
\hline & Variables & $\begin{array}{l}\text { Risk assets } \\
\text { ratio }\end{array}$ & $\begin{array}{l}\text { Loans to } \\
\text { total assets } \\
\text { ratio }\end{array}$ & $\begin{array}{c}\text { Customer } \\
\text { deposits to } \\
\text { total assets }\end{array}$ & $\begin{array}{l}\text { Loans to } \\
\text { deposits } \\
\text { ratio }\end{array}$ & $\begin{array}{l}\text { Cost to } \\
\text { income ratio }\end{array}$ \\
\hline \multirow{5}{*}{ Pre-crisis } & Mean-conventional & 20.8583 & 44.2267 & 66.5258 & 67.8008 & 36.3042 \\
\hline & Mean-Islamic & 28.8622 & 53.0244 & 60.3422 & 46.4744 & 81.4411 \\
\hline & t Stat & -2.8606 & -4.7807 & 3.3645 & 7.9927 & -10.5639 \\
\hline & $\mathrm{P}(\mathrm{T}<=\mathrm{t})$ two-tail & 0.1036 & 0.0411 & 0.0781 & 0.0153 & 0.0088 \\
\hline & t Critical two-tail & 4.3027 & 4.3027 & 4.3027 & 4.3027 & 4.3027 \\
\hline $\begin{array}{l}\text { During } \\
\text { crisis }\end{array}$ & Mean-conventional & 20.8458 & 54.9367 & 66.0400 & 67.9592 & 35.4817 \\
\hline
\end{tabular}




\section{CONCLUSION}

The current study examines the impact of oil crisis on the performance of selected banks of Bahrain. The performance of banks is assessed using profitability, efficiency, capital adequacy and liquidity ratios in the precrisis and crisis periods. Analyzing the variables, the results indicate that mean ROA, ROE, operating profit to total assets, cost to income ratios improved during crisis. The oil crisis had a negative impact on net interest income to total assets, net interest income to total income and loan to total assets ratios. Risk assets ratio, customer deposits to total assets and loan to deposits ratios are consistent during both the periods. Conventional banks performed better during the crisis as indicated by the profitability ratios. The results of the paired t-test on all banks reveal that there is no significant difference in the performance of banks in the pre-crisis and crisis period. Further, the t-test results indicate that there is a significant difference in the performance of conventional banks and Islamic banks in the pre-crisis period. However, there is no significant difference in the performance of conventional banks and Islamic banks during the crisis period. It can be concluded that the oil crisis did not have any significant impact on the performance of the banks. This result is similar to results of Poghosyan and Hesse (2009). Banks have taken measures to improve the performance during the oil crisis.

\section{REFERENCES}

1. Almsafir, M. K., Kim, W. G., \& Alsmadi, A. A. (2016). Islamic Banking versus Conventional Banking, During the Global Crisis: Bahrain. Research Journal of Finance and Accounting, 7(8), 183-193. Retrieved from http://iiste.org/ Journals/index.php/RJFA/article/ view/29992/30822

2. Alodayni, S. (2016). Oil Prices, Credit Risks in Banking Systems, and Macro-Financial Linkages across GCC Oil Exporters. International Journal of Financial Studies, 4(4), 1-14. http://dx.doi. org/10.3390/ijfs4040023Central Bank of Bahrain (2017). Retrieved from http://www.cbb.gov.bh/pagep-financial_sector_fact_sheet.htm

3. Central Bank of Bahrain (2017). Retrieved from http://www.cbb.gov. bh/pagep-financial_sector_fact_ sheet.htm

4. El-Katiri, L. (2017). Oil's Fall Is a Challenge for Gulf Economies, but Also an Opportunity. Retrieved from https://hbr.org/2016/03/oilsfall-is-a-challenge-for-gulf-economies-but-also-an-opportunity

5. Energy (2017). The Report: Bahrain 2016. Retrieved from http://www. oxfordbusinessgroup.com/bahrain-2016/energy

6. Ganguli, S. (2016). An economic analysis of sustainability of a potential GCC economic and monetary union during 2005-2014. World Journal of Entrepreneurship, Management and Sustainable Development, 12(3), 194-206.
Retrieved from http://www.emeraldinsight.com/doi/full/10.1108/ WJEMSD-01-2016-0005

7. Gulf states facing social and economic crisis as oil revenues crash (2017). Retrieved from http://www.climatechangenews. com/2015/02/19/gulf-states-facingsocial-and-economic-crisis-as-oilrevenues-crash/

8. Hawaldar, I. T., Lokesh, L., \& Biso, S. S. (2016a). An Empirical Analysis of Financial Performance of Retail and Wholesale Islamic Banks in Bahrain. American Scientific Research Journal for

Engineering, Technology, and Sciences (ASRJETS), 20(1), 137-147. Retrieved from http://asrjetsjournal. org/index.php/American_Scientific_Journal/article/view/1726

9. Hawaldar, I. T., Lokesha, Kumar, A. K., Pinto, P., \& Sison, S. M. (2017b). Performance Analysis of Commercial Banks in the Kingdom of Bahrain (2001-2015). International Journal of Economics and Financial Issues, 7(3), 729-737. Retrieved from https://www.econjournals.com/index.php/ijefi/article/ view/4325

10. Hawaldar, I. T., Pinto, P., Lokesha. (2016b). An empirical analysis of performance of retail and wholesale conventional banks in Bahrain. British Journal of Economics, Finance and Management Sciences, 12(1), 1-10. Retrieved from http://www.ajournal.co.uk/EFpdfs/EFvolume12(1)/
EFVol.12\%20(1)\%20Article\%201 pdf

11. Hawaldar, I. T., Rahiman, H. U., Rajesha T. M., \& Kumar N. K. R. (2017a). A Comparison of Financial Performance of Islamic and Conventional Banks in Bahrain. American Scientific Research Journal for Engineering, Technology, and Sciences (ASRJETS), 33(1), 100-110. Retrieved from http://asrjetsjournal. org/index.php/American_Scientific_Journal/article/view/3107

12. Hesse, H., \& Poghosyan, T. (2009). Oil prices and bank profitability: evidence from major oil-exporting countries in the Middle East and North Africa (IMF Working Paper, WP/16/161), 22 p. Was changed from $\mathrm{H}$. Hesse \& T. Poghosyan (2016). Oil prices and bank profitability: evidence from major oil-exporting countries in the Middle East and North Africa. In Financial Deepening and Post-Crisis Development in Emerging Markets (pp. 247-270). Palgrave Macmillan US (at 18th of March, 2019).

13. Khandelwal, Miyajima, and Santos (2016). The Impact of Oil Prices on the Banking System in the GCC (IMF Working Paper, WP/16/161). $22 \mathrm{p}$. Was added at 18th of March, 2019.

14. Strong financials give Bahrain global sway (2017). Retrieved from https://www.oxfordbusinessgroup. com/overview/leading-examplestrong-financial-fundamentals-continue-keep-sector-globallycompetitive 
APPENDIX

Source: World Bank.

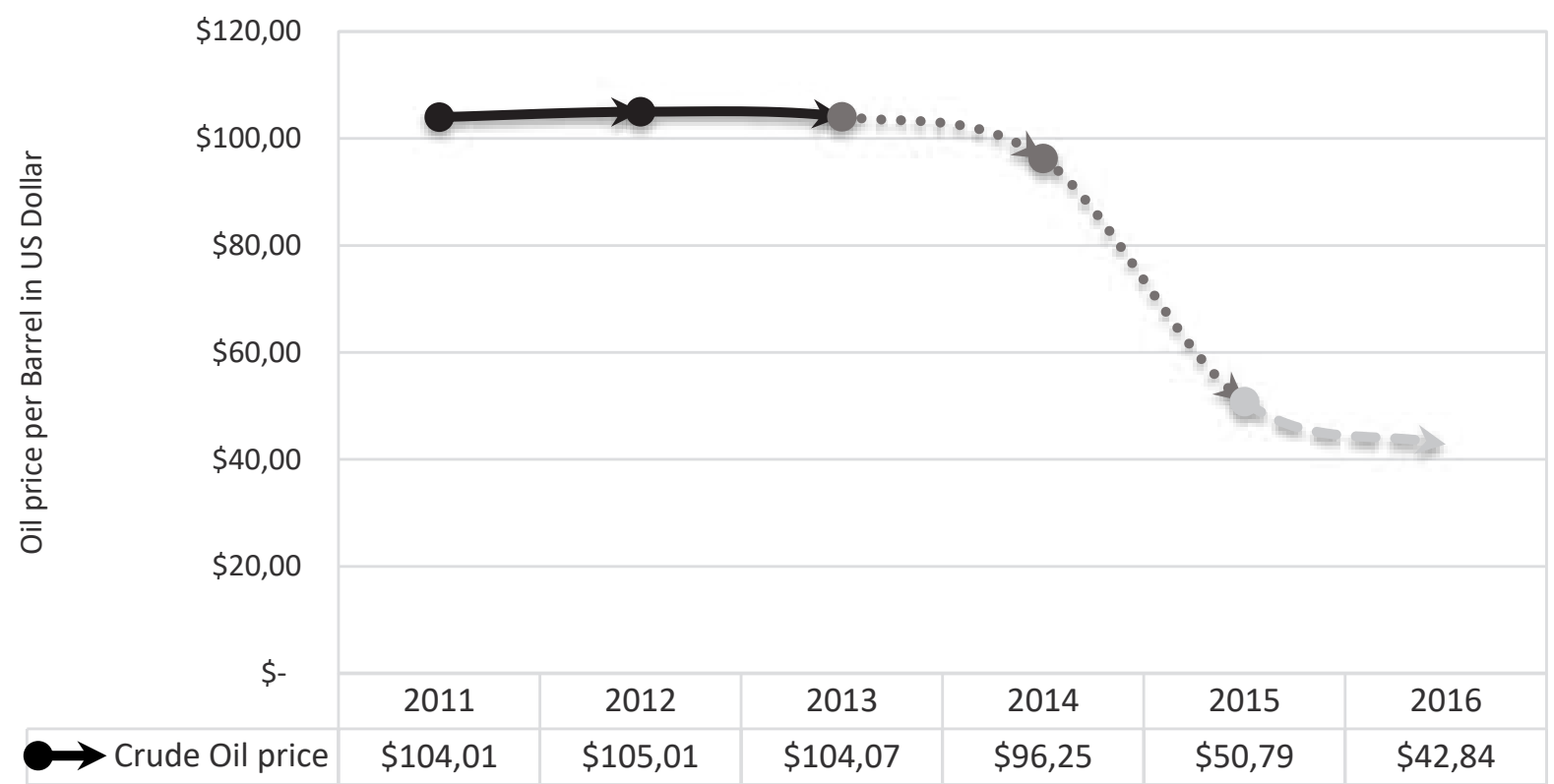

Figure 1. Crude oil price per barrel in US dollar 